\title{
Evaluation of Soil Fertility and Heavy Metal Contamination in Abandoned Regions of Tin Mine,China
}

\author{
Shao Jinping ${ }^{1}$, Song Xiangbin ${ }^{2}$, Li Guixiang ${ }^{1,{ }^{*},}$ Zhang Qun ${ }^{1}$,Fang Xiangjing ${ }^{1}$, \\ He Liping ${ }^{1}$
}

1. Yunnan Academy of Forestry, 650000 , Kunming,China; 2.Southwest Forestry University, Environmental Science and Engineering, 650224, Kunming,China

KEYWORD: Mine tailings; Soil fertility; Heavy metal contamination; Contamination assessment ABSTRACT: Based on determination of the contents of soil nutrients elements and heavy metals for the four tin mine tailings (Niubahuang, Laochang, Kafang and Southern) in Gejiu, the heavy metal pollution of four tin mine tailings were assessed with the single contamination index method, the comprehensive contamination index method, the geoaccumulation index method and the potential ecological risk index method. The results showed that:(1)Soil $\mathrm{pH}$ of four tin mine tailings was more than 7.5, for alkaline soil. The soil fertility of four tin mine tailings was poor, the soil organic matter soil fertility levels were between VI level, total N、P、K and available P index of soil fertility level basically in III $\sim$ VI, soil fertility index of K available were grade II, the soil fertility order: the Laochang $>$ the Kafang $>$ the Southern $>$ the Niu banghuang. (2)In the four tin mine tailings, the average contents of $\mathrm{Mn}, \mathrm{Cu}, \mathrm{Pb}, \mathrm{Cd}$ and $\mathrm{Zn}$ were $5700.98 \mathrm{mg} / \mathrm{kg}, 2041.19 \mathrm{mg} / \mathrm{kg}$, $7164.72 \mathrm{mg} / \mathrm{kg}, 21.33 \mathrm{mg} / \mathrm{kg}$ and $2146.81 \mathrm{mg} / \mathrm{kg}$. According to the mean size sorting are: $\mathrm{Pb}>\mathrm{Mn}>$ $\mathrm{Zn}>\mathrm{Cu}>\mathrm{Cd}$. According to the single contamination index and the comprehensive contamination index , all of heavy metal contamination grades were high pollution. According to the Hankanson potential ecological risk index evaluation results: $\mathrm{Mn}$ and $\mathrm{Zn}$ minor ecological risk, $\mathrm{Cu}, \mathrm{Pb}$ and $\mathrm{Ca}$ for strong ecological risk. Cumulative Index to evaluate the results: Mn pollution level was 3, $\mathrm{Cu}$, $\mathrm{Pb}, \mathrm{Cd}$ contamination level were 6 , Zn pollution level was 4 to 5 .

\section{INTRODUCTION}

Mine tailings is used to refer to the land by destruction or pollution in the process of mining production without governance and hard to use, such as waste rock pile up, abandoned mining land, tailings, etc. China is one of the world's countries with much more mine tailings, the increasing of mine tailings and extremely tense land resources become to a pair of sharp contradictions. It is urgent for the ecological rehabilitation and reclamation. However, the soil structure in the mine tailings is very poor and lack of nutrients with very high content of heavy metal, as well as with very big differences of soil heavy pollution, pollutant type and soil arid condition in different mine tailings, and very difficult for vegetation restoration. Therefore, during the vegetation restoration of the wasted lands, to understand the soil fertility condition and heavy metals pollution condition is very important for the restoration. Gejiu is a super large mining area for tin and copper polymetallic, it is clear that the cumulative non-ferrous metals reserves 4.76 million tons, of which, the tin deposit of 1.7211 million tons, mining result in large area of abandoned land in Gejiu. In view of this, the analysis on the samples taken from the four mine tailings (Niubahuang, Laochang, Kafang and Southern) of Gejiu were made in this paper in order to study the soil heavy metal pollution condition in the individual mine tailing so as to provide a scientific basis for the governance and ecological restoration in a proper way.

\section{MATERIALS AND METHODS}

\section{Brief introduction of Project site}

Gejiu city, with its famous name of "tin capital" in the world, is located in the south ofYunnan, across between E103 28 '07' $103^{\circ} 09^{\prime}$ '14, "N23 18' 56 $\sim 23^{\circ} 21$ '39", it is a industrial city for the production of lead, $\mathrm{Zn}$, copper and other non-ferrous metals with focus on tin production. With high difference in elevation and very clear vertical climate distribution, it covers five climate 
zones, including north tropics, south Asian tropical, subtropical, tropical north and south temperate zone. Short-time sunlight throughout the year, small difference in annual temperature, long frostfree period and clearly dry and rainy seasons. Mild climate, annual average sunlight $1986.6 \mathrm{~h}$, annual average temperature $16.4{ }^{\circ} \mathrm{C}$, annual rainfall of $890 \mathrm{~mm}$. Soil types in Gejiu are varied and soil distribution in different elevation, such as latosolic red soil, red soil, yellow soil, yellow brown soil, limestone soil. The four mine tailings (Niubahuang, Laochang, Kafang and Southern) were selected for the study.

\section{Sample collection and pretreatment}

Sample collection: The field investigation and sample collection in the four sites was made in June 2014 in Gejiu, according to the terrain characteristics of abandoned land in the four sites, as well as the requirements of "Technical Specification for Soil Environmental Quality Monitoring (NY/T395 2000)", respectively by the methods of "S" points and strip points for sampling, $0 \sim 20$ $\mathrm{cm}$ of surface soil was collected from the 14 sampling points, each soil sample consists of soil samples collected from multiple points and divided by four points. About $1 \mathrm{~kg}$ of each sample was taken and put in bag with label for the laboratory analysis.

\section{Determination method}

The determination of soil nutrients: soil $\mathrm{pH}$ measurement according to the method of "Analysis of Soil Agro-chemistry", a 1:2.5 ratio method was used to determine soil and water conservation; Determination of soil organic matter-heated potassium dichromate oxidation-external heating method; Soil total nitrogen, hydrolyze nitrogen determination - the solution diffusion method, alkali solution diffusion method; Soil total phosphorus, available phosphorus - alkali soluble - molybdenum antimony colorimetric method and extraction using hydrochloric acid - sulfuric acid; Soil total potassium, available potassium, alkali soluble - flame photometry, $1 \mathrm{~mol} / \mathrm{L}$ acetic acid ammonium leaching - flame photometry.

The determination of soil heavy metals: soil samples using $\mathrm{HNO}_{3}+\mathrm{HCl}+\mathrm{HClO}_{4}(4 \mathrm{ml}+1 \mathrm{ml}+1$ $\mathrm{ml}$ ), flame atomic absorption spectrophotometric method was used for the determination of $\mathrm{Mn}, \mathrm{Pb}$, $\mathrm{Cu}, \mathrm{Cd}, \mathrm{Zn}$ content.

\section{Evaluation of heavy metal pollution and its standard Single contamination index method}

Single contamination index method is one of the domestic general evaluation of soil, water, atmosphere and the method of river sediment pollution of heavy metals, the calculation formula: $P_{i}=\frac{C_{i}}{S_{i}}$, $P_{i}$ - certain heavy metal elements in soil mass fraction of i; $C_{i}$ - measured concentration of heavy metal elements in soil, $\mathrm{mg} / \mathrm{kg}$. $S_{i}$ - the threshold of heavy metals $\mathrm{i}$ in classIII according to soil environment quality standard (GB 15618-1995), mg/kg.

\section{Comprehensive contamination index method}

Nemerow index method is one of the most commonly used method currently at home and abroad to calculate comprehensive pollution index, which is a kind of environmental quality index for both maximum extreme or prominent type weighting contamination, the calculation formula:

$$
P \mathrm{c}=\sqrt{\frac{\left.\left(\overline{P_{i}}\right)^{2}+\left[\max \left(P_{i}\right)\right]^{2}\right]}{2}}
$$

in which $P_{\mathrm{c}}$-soil heavy metal pollution index; $\bar{P}_{i}$ - the average index of heavy metal elements in soil; $\max \left(P_{i}\right)$ - the greatest single contaminants in the soil pollution index. 
Table 1 The classification of soil heavy metal pollution standards

\begin{tabular}{|c|c|c|c|c|}
\hline \multirow[t]{2}{*}{ class } & \multicolumn{2}{|c|}{$\begin{array}{l}\text { Single contami- } \\
\text { nation in- } \\
\operatorname{dex}\left(P_{i}\right) \text { standard }\end{array}$} & \multicolumn{2}{|c|}{$\begin{array}{l}\text { Comprehensive } \\
\text { contamination in- } \\
\operatorname{dex}\left(P_{C}\right) \text { standard }\end{array}$} \\
\hline & index & class & index & class \\
\hline I & $P_{i} \leq 0.7$ & clean & $P c \leq 0.7$ & safe \\
\hline II & $\begin{array}{c}1 \leq P_{i}< \\
?\end{array}$ & $\begin{array}{l}\text { Mild } \\
\text { pollu- }\end{array}$ & $\begin{array}{l}0.7< \\
P_{r} \leq 1\end{array}$ & alert \\
\hline III & $\begin{array}{c}2 \leq P_{i}< \\
3\end{array}$ & $\begin{array}{l}\text { Mod- } \\
\text { erate }\end{array}$ & $1<_{P c} \leq 2$ & $\begin{array}{l}\text { Mild } \\
\text { pollu- }\end{array}$ \\
\hline IV & $P_{i} \geq 3$ & $\begin{array}{l}\text { Heavy } \\
\text { pollu- }\end{array}$ & $2<_{P c} \leq 3$ & $\begin{array}{l}\text { Mod- } \\
\text { erate }\end{array}$ \\
\hline $\mathrm{V}$ & & & $P c>3$ & $\begin{array}{l}\text { Heavy } \\
\text { pollu- }\end{array}$ \\
\hline
\end{tabular}

\section{Geoaccumulation index method}

Geoaccumulation index method is scientists at the university of Heidelberg, Germany Institute of Sediment Mr. Muller proposed in 1969, and which has been popular used by scholars both at home and abroad for the assessment of soil heavy metal pollution in recent years, its computation formula is:

$I_{\text {geo }}=\log _{2}\left(\frac{C_{n}}{k \times B_{n}}\right)$

$I_{\text {geo }}$ - accumulated index; $C_{n}$ - the measured values of heavy metal elements in the sample, $\mathrm{mg} / \mathrm{kg}$;

$B_{n}$ - geochemical background values of the element

Table2 The relation between geoaccumulation index and pollution degree

\begin{tabular}{ccccccccc}
\hline$I_{\text {geo }}$ & $I_{\text {geo }}<\mathbf{0}$ & $\mathbf{0} \leq I_{\text {geo }}<\mathbf{1}$ & $\mathbf{1} \leq I_{\text {geo }}<\mathbf{2}$ & $\begin{array}{l}\mathbf{2} \leq I_{\text {geo }}< \\
\mathbf{3}\end{array}$ & $\begin{array}{l}\mathbf{3} \leq \\
<\mathbf{4}\end{array}$ & $I_{\text {geo }}$ & $\mathbf{4} \leq I_{\text {geo }}<\mathbf{5}$ & $I_{\text {geo }}>\mathbf{5}$ \\
\hline Class & 0 & 1 & 2 & 3 & 4 & 5 & 6
\end{tabular}

Pollu-

\begin{tabular}{|c|c|c|c|c|}
\hline $\begin{array}{l}\text { Pollu- } \\
\text { tionde- non } \\
\text { gree }\end{array}$ & $\begin{array}{l}\text { Mild to middle } \\
\text { middle }\end{array}$ & $\begin{array}{l}\text { Middle to } \\
\text { heavy }\end{array}$ & heavy & $\begin{array}{l}\text { Heavy to extreme } \\
\text { heavy }\end{array}$ \\
\hline
\end{tabular}

in the sediments. In this study, the soil environmental quality background value of Yunnan province was used as the background value, $\mathrm{mg} / \mathrm{kg}$; $\mathrm{K}$ - correction coefficient, the value of 1.5.

\section{Potential ecological risk index method}

Potential ecological risk index method for the assessment was proposed by a 1980 Swedish scientist Mr. Hakanson in 1980 from the point of view of sedimentology, used in assessment of soil or sediment degree of heavy metal pollution and potential ecological risk, the calculation formula is:

$(R I)=\sum_{i=1}^{n} E_{r}^{i}(1-4)$

Of which, the single potential ecological risk index $\left(E_{r}^{i}\right)=T_{r}^{i} \times C_{f}^{i}(1-5)$

The pollution of heavy metal pollutants coefficient

$\left(C_{f}^{i}\right)=C_{s}^{i} / C_{n}^{i}(1-6)$ 
Among them, $C_{s}^{i}$ - measured content of heavy metal elements i in soil, $\mathrm{mg} / \mathrm{kg} ; C_{n}^{i}$ - to calculate the required ratio value, generally in the evaluation the soil environmental standard values of the country used as a reference ratio, $\mathrm{mg} / \mathrm{kg}$. ); $T_{r}^{i}$ is for a single pollutant toxicity response parameters.

Table3 The Hankanson potential ecological risk evaluation and classification relations

\begin{tabular}{|c|c|c|c|}
\hline $\begin{array}{l}\text { Potential } \\
\text { risk } E_{r}^{i} \text { scope }\end{array}$ & $\begin{array}{l}\text { Single contamina- } \\
\text { tion risk degree }\end{array}$ & $\begin{array}{l}\text { Potential } \\
\text { scope } R I<\end{array}$ & $\begin{array}{l}\text { Total potential risk } \\
\text { degree }\end{array}$ \\
\hline$E_{r}^{i}<40$ & mild & $\leq R I<150$ & Mild \\
\hline $40 \leq E_{r}^{i}<80$ & moderate & $150 \leq R I<300$ & Moderate \\
\hline $80 \leq E_{r}^{i}<160$ & heavy & $300 \leq R I<600$ & heavy \\
\hline $160 \leq E_{r}^{i}<320$ & Very heavy & $R I \geq 600$ & Very heavy \\
\hline$E_{r}^{i} \geq 320$ & Extreme heavy & & \\
\hline
\end{tabular}

\section{RESULT AND ANALYSIS}

Soil Nutrients content in mine tailing

Table4 The Contents of soil nutrient elements in different mine tailings

\begin{tabular}{|c|c|c|c|c|c|c|c|c|}
\hline \multirow[b]{2}{*}{ Site } & \multirow[b]{2}{*}{$\mathbf{p H}$} & \multirow[b]{2}{*}{$\begin{array}{l}\text { Organic } \\
\text { mat- } \\
\operatorname{ter}(g / k g)\end{array}$} & \multicolumn{2}{|r|}{$\mathbf{N}$} & \multicolumn{2}{|c|}{$\mathbf{P}$} & \multicolumn{2}{|c|}{$\mathbf{K}$} \\
\hline & & & $\begin{array}{l}\text { Total N } \\
\text { (g/kg) }\end{array}$ & $\begin{array}{l}\text { Hydrolyz- } \\
\text { able } \\
\mathrm{N}(\mathrm{mg} / \mathrm{kg})\end{array}$ & $\begin{array}{l}\text { Total P } \\
\text { (g/kg) }\end{array}$ & $\begin{array}{l}\text { Effective } \\
P \\
(\mathrm{mg} / \mathrm{kg})\end{array}$ & $\begin{array}{l}\text { Total K } \\
\text { (g/kg) }\end{array}$ & $\begin{array}{l}\text { Available } \\
\mathrm{K} \\
(\mathrm{mg} / \mathrm{kg})\end{array}$ \\
\hline $\begin{array}{l}\text { Niuba- } \\
\text { huang }\end{array}$ & 7.82 & 4.691 & 0.801 & 116.45 & 0.423 & 3.348 & 10.612 & 175.328 \\
\hline $\begin{array}{l}\text { Lao- } \\
\text { chang }\end{array}$ & 7.78 & 1.476 & 1.161 & 170.188 & 0.461 & 9.971 & 9.553 & 193.171 \\
\hline Kafang & 7.61 & 7.414 & 0.726 & 154.630 & 0.722 & 7.751 & 8.965 & 160.173 \\
\hline $\begin{array}{l}\text { south- } \\
\text { ern }\end{array}$ & 7.68 & 2.671 & 0.433 & 83.545 & 0.896 & 10.972 & 16.833 & 129.397 \\
\hline
\end{tabular}

Table5 The classification of soil nutrient standards

\begin{tabular}{cccccccc}
\hline $\begin{array}{l}\text { Nu- } \\
\text { trient }\end{array}$ & $\begin{array}{l}\text { Organic } \\
\text { mat- } \\
\text { ter(g/kg) }\end{array}$ & $\begin{array}{l}\text { Total N } \\
(\mathbf{g} / \mathbf{k g})\end{array}$ & $\begin{array}{l}\text { Hydrolyz- } \\
\text { able } \\
\mathbf{N}(\mathbf{m g} / \mathbf{k g})\end{array}$ & $\begin{array}{l}\text { Total P } \\
(\mathbf{g} / \mathbf{k g})\end{array}$ & $\begin{array}{l}\mathbf{E f f e c t i v e} \\
\mathbf{P} \\
\mathbf{( m g / k g})\end{array}$ & $\begin{array}{l}\text { Total K } \\
(\mathbf{g} / \mathbf{k g})\end{array}$ & $\begin{array}{l}\text { Available K } \\
(\mathbf{m g} / \mathbf{k g})\end{array}$ \\
\hline I & $>40.00$ & $>2.00$ & $>150.00$ & $>1.00$ & $>40.00$ & $>25.00$ & $>200.00$ \\
II & $30.00 \sim$ & $1.50 \sim$ & $120.00 \sim$ & $0.80 \sim$ & $20.00 \sim$ & $20.00 \sim$ & $150.00 \sim$ \\
& 40.00 & 2.00 & 150.00 & 1.00 & 40.00 & 25.00 & 200.00 \\
III & $20.00 \sim$ & $1.00 \sim$ & $90.00 \sim$ & $0.60 \sim$ & $10.00 \sim$ & $15.00 \sim$ & $100.00 \sim$ \\
& 30.00 & 1.50 & 120.00 & 0.80 & 20.00 & 20.00 & 150.00 \\
IV & $10.00 \sim$ & $0.75 \sim$ & $60.00 \sim$ & $0.40 \sim$ & $5.00 \sim$ & $10.00 \sim$ & $50.00 \sim$ \\
& 20.00 & 1.00 & 90.00 & 0.60 & 10.00 & 15.00 & 100.00 \\
V & $6.00 \sim 10.00$ & $0.50 \sim$ & $30.00 \sim$ & $0.20 \sim$ & $3.00 \sim$ & $5.00 \sim$ & $30.00 \sim 50.00$ \\
VI & $<6.00$ & $<0.50$ & $<30.00$ & $<0.40$ & $<3.00$ & $<5.00$ & $<30.00$ \\
\hline
\end{tabular}

(Note: a:I- very rich, II-rich, III-appropriate amount, IV-less, V-more less,VI-much more less)

The determination results of the soil nutrient elements are shown in table 4. Soil pH measurement results shows that the soil $\mathrm{pH}$ were greater than 7.5 (when to neutral soil $\mathrm{pH}$ at $6.5 \sim 7.5$ ), as the al- 
kaline soil, showed that the soil acidification did not happen. Table 4 shows that soil fertility levels in different mine tailings are varied. According to soil fertility index classification reference index 5 , in general the soil fertility level in the four sites level is lower, the grading index can be seen in table 6 on the basis of nutrient grading standards promulgated by the $2^{\text {nd }}$ national soil census.

The table 6 shows that the level of the organic soil fertility index mostly at level VI, and total N, total $\mathrm{P}$ and soil fertility index such as effective $\mathrm{P}$ and total $\mathrm{K}$ almost at level between III $\sim$ VI basically, available K of soil fertility index mostly at level II. The result shows that the organic matter, total $\mathrm{N}$, total $\mathrm{P}$, effective $\mathrm{P}$ and total $\mathrm{K}$ become the main factors limiting the soil fertility in tin mine tail-

Table6 The soil fertility grade of different mine tailings

\begin{tabular}{|c|c|c|c|c|c|c|c|}
\hline \multirow{2}{*}{$\begin{array}{l}\text { Mine } \\
\text { tailing } \\
\text { site }\end{array}$} & \multirow{2}{*}{$\begin{array}{l}\text { Organic } \\
\text { matter }\end{array}$} & \multicolumn{2}{|r|}{$\mathbf{N}$} & \multicolumn{2}{|r|}{$\mathbf{P}$} & \multicolumn{2}{|c|}{$\mathbf{K}$} \\
\hline & & Total N & $\begin{array}{l}\text { Hydrolyzable } \\
\text { N }\end{array}$ & Total P & $\begin{array}{l}\text { Effective } \\
P\end{array}$ & Total K & $\begin{array}{l}\text { Available } \\
\text { K }\end{array}$ \\
\hline $\begin{array}{l}\text { Niuba- } \\
\text { huang }\end{array}$ & VI & IV & III & IV & $\mathrm{V}$ & IV & II \\
\hline $\begin{array}{l}\text { Lao- } \\
\text { chang }\end{array}$ & VI & II & I & IV & IV & V & II \\
\hline $\begin{array}{c}\text { Kafano } \\
\text { ings. } \\
\text { huang } \\
\text { Lany: }\end{array}$ & $\begin{array}{l}\mathrm{V} \\
\text { order for } \\
\text { he determi } \\
2011 \text { ) and }\end{array}$ & the soil & $\begin{array}{l}\text { I } \\
\text { ility in the for } \\
\text { are the same a }\end{array}$ & $\begin{array}{l}\text { III } \\
\text { sites is: } \\
\text { the resea }\end{array}$ & $\begin{array}{l}\text { IV } \\
\text { lochang > } \\
\text { result by }\end{array}$ & $\begin{array}{c}\mathrm{V} \\
\text { fang }>\text { Sou } \\
\text { Dongmei }\end{array}$ & $\begin{array}{c}\text { II } \\
\text { n >Niuba- } \\
07 \text { ), Wang }\end{array}$ \\
\hline
\end{tabular}

Table7 The analysis of the characteristics of heavy metal content of wasteland soil

\begin{tabular}{|c|c|c|c|c|c|}
\hline site & $\operatorname{Mn}(\mathrm{mg} / \mathrm{kg})$ & $\mathrm{Cu}(\mathrm{mg} / \mathrm{kg})$ & $\mathrm{Pb}(\mathrm{mg} / \mathrm{kg})$ & $\mathrm{Cd}(\mathrm{mg} / \mathrm{kg})$ & $\mathrm{Zn}(\mathrm{mg} / \mathrm{kg})$ \\
\hline \multirow{2}{*}{ Niubahuang } & $6091.7425 \pm$ & $2836.1148 \pm$ & $7256.8967 \pm$ & $24.1415 \pm 12.857$ & $2514.6514 \pm$ \\
\hline & 580.7169 & 994.6643 & 2261.4010 & 4 & 601.6313 \\
\hline \multirow{2}{*}{ Laochang } & $5602.3481 \pm$ & $2402.2517 \pm$ & $6253.8750 \pm$ & $34.2361 \pm 19.537$ & $1834.8240 \pm$ \\
\hline & 1950.1010 & 969.8359 & 1823.6680 & 8 & 540.0265 \\
\hline \multirow{2}{*}{ Kafang } & $5410.8190 \pm$ & $1572.4359 \pm$ & $7832.8820 \pm$ & \multirow{2}{*}{$15.8387 \pm 9.7998$} & $2626.4840 \pm$ \\
\hline & 1109.6250 & 792.0118 & 2469.134 & & 1280.7840 \\
\hline \multirow{2}{*}{ Southern } & $5699.0490 \pm$ & $1485.8745 \pm$ & $7315.5240 \pm$ & \multirow{2}{*}{$11.1016 \pm 7.5525$} & $1611.2640 \pm$ \\
\hline & 1875.748 & 832.1135 & 2576.2220 & & 180.3292 \\
\hline Class II & l & 50.00 & 250.00 & 0.3000 & 200.00 \\
\hline Class III & / & 400.00 & 500.00 & 1.000 & 500.00 \\
\hline $\begin{array}{l}\text { Soil envi- } \\
\text { ronment } \\
\text { background } \\
\text { value of YN }\end{array}$ & 515.00 & 28.70 & 35.70 & 0.083 & 86.00 \\
\hline
\end{tabular}


Table8 The heavy metal pollution of wasteland soil index of single contamination and Nemero comprehensive pollution index evaluation table

\begin{tabular}{|c|c|c|c|c|c|c|c|}
\hline \multirow{2}{*}{ Site } & \multicolumn{5}{|c|}{$P_{i}$} & \multirow{2}{*}{$P c$} & \multirow{2}{*}{ Level } \\
\hline & Mn & $\mathbf{C u}$ & $\mathbf{P b}$ & Cd & $\mathbf{Z n}$ & & \\
\hline Niubahuang & / & 7.09 & 14.51 & 24.14 & 5.03 & 19.29 & $\begin{array}{l}\text { Heavy pollu- } \\
\text { tion }\end{array}$ \\
\hline Laochang & / & 6.01 & 12.51 & 34.24 & 3.67 & 26.19 & $\begin{array}{l}\text { Heavy pollu- } \\
\text { tion }\end{array}$ \\
\hline Kafang & / & 3.93 & 14.77 & 15.84 & 5.25 & 13.23 & $\begin{array}{c}\text { Heavy Pollu- } \\
\text { tion }\end{array}$ \\
\hline Southern & / & 3.71 & 14.63 & 11.10 & 3.22 & 11.85 & $\begin{array}{l}\text { Heavy pollu- } \\
\text { tion }\end{array}$ \\
\hline Mean value & & 5.19 & 14.11 & 21.33 & 4.29 & 17.64 & $\begin{array}{l}\text { Heavy Pollu- } \\
\text { tion }\end{array}$ \\
\hline Class III & 1 & 400.00 & 500.00 & 1.00 & 500.0 & & \\
\hline
\end{tabular}

\section{Heavy metal content in mine tailing}

The statistical analysis of soil heavy metal content in the sites are shown in table 7: The average content of five different kinds of heavy metals $(\mathrm{Mn}, \mathrm{Cu}, \mathrm{Pb}, \mathrm{Cd}, \mathrm{Zn})$ are respectively: 5700.9897 $\mathrm{mg} / \mathrm{kg}, 2041.1963 \mathrm{mg} / \mathrm{kg}, 7164.7249 \mathrm{mg} / \mathrm{kg}, 21.3295 \mathrm{mg} / \mathrm{kg}$ and $2146.8060 \mathrm{mg} / \mathrm{kg}$. The order based on the average content is: $\mathrm{Pb}>\mathrm{Mn}>\mathrm{Zn}>\mathrm{Cu}>\mathrm{Cd}$. With reference to the state soil environment quality standard (GB15618-1995), the content of $\mathrm{Cu}, \mathrm{Pb}, \mathrm{Cd}$ and $\mathrm{Zn}$ are 40.82 times, 28.66 times, 71.09 times and 10.73 times respectively more than the 2nd class standard while $\mathrm{Cu}, \mathrm{Pb}, \mathrm{Cd}$ and $\mathrm{Zn}$ also goes beyond level three based on the soil environment quality standard, and 5.10 times, 14.33 times, 21.33 times and 4.29 times respectively. Therefore, it can be initially determined that in the mine tailings of Gejiu, Cd pollution is the most serious. In addition, the content of $\mathrm{Mn}$ in all kinds of soils is relatively high, this may be related to the background value of soil itself.

Assessment of the heavy metal pollution of wasteland soil index

\section{Assessment of soil pollution based on single contamination and Nemero comprehensive pollu- tion index}

The national soil environmental quality standard is used in this paper to give an assessment of the pollution by heavy metals $(\mathrm{Mn}, \mathrm{Cu}, \mathrm{Pb}, \mathrm{Cd}, \mathrm{Zn})$ in tin mine tailings with single contamination pollution index and Nemero comprehensive pollution index. Due to no any limitation on Mn element in view of the national soil environmental quality standard, so the evaluation on pollution only made for the other four elements in the study, the results as shown in table 8. It Can be seen from the single contamination pollution index, the heavy metal $\mathrm{Cu}, \mathrm{Pb}, \mathrm{Cd}$ and $\mathrm{Zn}$ in the different site the average value of their single contamination pollution index is 5.19, 14.11, 21.33 and 5.19, respectively. Among which Cd pollution in Laochang is the most serious with pollution index up to 34.24. Therefore, $\mathrm{Cd}$ is the main pollution contamination in the wasteland. According to the national soil environmental quality standard, all sites are heavy pollution. Compared with single contamination pollution index, multi-contamination comprehensive evaluation results of pollution index is different, which shows the effect of contamination with high concentration on soil environmental quality and the range between $11.85 \sim 26.19$, with mean value of 17.64 , the comprehensive pollution index is greater than three and are heavy pollution according to the national soil environmental quality standard.

\section{Assessment of soil pollution based on geoaccumulation index}

The impacts from heavy metals on the environment caused by natural and human activities is considered by Geoccumulation index, also the changes of background value might be caused by natural diagenesis. Therefore, in this paper, soil environmental background value of Yunnan province was 
taken as the evaluation standard. The table 9 shows that based on the soil environmental background value in Yunnan province and the geoaccumulation index, the pollution of $\mathrm{Mn}$ in soil surface ranks at grade III in the four sites, and the pollution degree is at moderate level; $\mathrm{Cu}, \mathrm{Pb}, \mathrm{Cd}$ pollution are at grade VI and the pollution is very serious pollution; $\mathrm{Zn}$ pollution is at $4 \sim 5$, pollution is extremely serious pollution. In addition to $\mathrm{Mn}$ for middle level pollution in the abandoned land, the heavy metal element of $\mathrm{Cu}, \mathrm{Pb}, \mathrm{Cd}$, and $\mathrm{Zn}$ are extremely serious pollution to the land. According to the mean value of $I_{\text {geo }}$, the order for the pollution degree by the heavy metal elements: the $\mathrm{Cd}>\mathrm{Pb}>\mathrm{Cu}>\mathrm{Zn}>\mathrm{Mn}, \mathrm{Cd}$ and $\mathrm{Pb}$ are extremely serious pollution and the main contamination in the sites.

\section{Assessment of soil pollution based on geoaccumulation index}

Potential ecological risk index $\left(E_{r}^{i}\right)$ of single heavy metal in the four sites and the potential ecological risk index (RI) of the five different heavy metals, as well as the reference value based on the environmental background value of Yunnan are shown in table 10 refs. The table 10 shows that the order for the potential ecological risk index $\left(E_{r}^{i}\right)$ of five heavy metal elements according to the average size in the order: $\mathrm{Cd}>\mathrm{Pb}>\mathrm{Cu}>\mathrm{Zn}>\mathrm{Mn}$. Among them, there is no big difference for the po-

Table9 The geoaccumulation index of heavy metal of wasteland soil

\begin{tabular}{|c|c|c|c|c|c|c|c|c|c|c|}
\hline \multirow[b]{2}{*}{ site } & \multicolumn{10}{|c|}{$I_{g e o}$} \\
\hline & Mn & $\begin{array}{c}\text { Index } \\
\text { class }\end{array}$ & $\mathbf{C u}$ & $\begin{array}{c}\text { Index } \\
\text { class }\end{array}$ & $\mathbf{P b}$ & $\begin{array}{c}\text { Index } \\
\text { class }\end{array}$ & Cd & $\begin{array}{c}\text { Index } \\
\text { class }\end{array}$ & Zn & $\begin{array}{l}\text { Index } \\
\text { class }\end{array}$ \\
\hline Niubahuang & 2.98 & 3 & 6.04 & 6 & 7.08 & 6 & 7.60 & 6 & 4.28 & 5 \\
\hline Laochang & 2.88 & 3 & 5.80 & 6 & 6.87 & 6 & 8.10 & 6 & 3.83 & 4 \\
\hline Kafang & 2.81 & 3 & 5.19 & 6 & 7.19 & 6 & 6.99 & 6 & 4.45 & 5 \\
\hline Southern & 2.88 & 3 & 5.11 & 6 & 7.09 & 6 & 6.48 & 6 & 3.64 & 4 \\
\hline Mean value & 2.88 & 3 & 5.54 & 6 & 7.06 & 6 & 7.29 & 6 & 4.05 & 5 \\
\hline $\begin{array}{l}\text { Soil environment } \\
\text { background value of } \\
\text { YN }(\mathrm{mg} / \mathrm{kg})\end{array}$ & 515 & & 28.7 & & 35.7 & & 0.083 & & 86 & \\
\hline
\end{tabular}

tential ecological risk index of $\mathrm{Mn}$ in the four sites and is between $10.51 \sim 10.51$, with a mean value of 11.07; The potential ecological risk index of $\mathrm{Cu}$ ranging between $258.86 \sim 494.10$; the potential ecological risk index of $\mathrm{Pb}$ between $875.89 \sim 1016.37$; The potential ecological risk index of $\mathrm{Cd}$ range is $4012.63 \sim 12374.49$; the potential ecological risk index of $\mathrm{Zn}$ in the range of $18.74 \sim 30.54$. According to Hankanson potential ecological risk assessment standard, $\mathrm{Cu}, \mathrm{Pb}$ and $\mathrm{Cd}$ in the four sites are extreme heavy ecological $\operatorname{risk}\left(E_{r}^{i} \geq 320\right)$; $\mathrm{Mn}$ and $\mathrm{Zn}$ are mild ecological risk $\left(E_{r}^{i}<40\right)$. Based on the potential ecological risk index (RI) of various of heavy metals, the ecological risks are extremely heavy in the four sites ( $\mathrm{RI} \geq 600$ ), this is because the risk index of $\mathrm{Cu}, \mathrm{Pb}$ and $\mathrm{Cd}$ is bigger than the others, and the result is consistent with the comprehensive pollution index assessment. 
Table10 The potential ecological risk index $\left(E_{r}^{i}\right)$ and potential ecological risk index $(R I)$ of heavy metals of wasteland soil

\begin{tabular}{|c|c|c|c|c|c|c|c|}
\hline \multirow{2}{*}{ site } & \multicolumn{5}{|c|}{$E_{r}^{i}$} & \multirow{2}{*}{$R I$} & \multirow{2}{*}{$\begin{array}{l}\text { Potential } \\
\text { ecological }\end{array}$} \\
\hline & Mn & $\mathrm{Cu}$ & $\mathbf{P b}$ & Cd & $\mathbf{Z n}$ & & \\
\hline Niubahuang & 11.83 & 494.10 & 1016.37 & 8725.84 & 29.24 & 10277. & Extreme \\
\hline Laochang & 10.88 & 418.51 & 875.89 & 12374.49 & 21.34 & 13701. & Extreme \\
\hline Kafang & 10.51 & 273.94 & 1097.04 & 5312.64 & 30.54 & 6724.6 & Extreme \\
\hline Southern & 11.07 & 258.86 & 1024.58 & 4012.63 & 18.74 & 5325.8 & Extreme \\
\hline$E_{r}^{i}$ mean value & 11.07 & 361.35 & 1367.33 & 7606.4 & 24.97 & & \\
\hline Pollution degree & Mild & Very & Extreme & Extreme & Mild & & \\
\hline $\begin{array}{l}\text { Soil environment } \\
\text { hackoround valıe of }\end{array}$ & 515 & 287 & 357 & 0083 & 860 & & \\
\hline
\end{tabular}

\section{CONCLUSION AND SUGGESTION}

a. All the organic soil fertility index level mostly at VI level while the soil fertility for other elements such as total $\mathrm{N}$, total $\mathrm{P}$, effective $\mathrm{P}$ and total $\mathrm{K}$ such as effective $\mathrm{P}$ at the level between III VI basically, soil fertility of available K at level II mostly.Tthe soil fertility size order: Laochang > Kafang $>$ Southern $>$ Niubahuang.

b. The average content of five different heavy metals ( $\mathrm{Mn}, \mathrm{Cu}, \mathrm{Pb}, \mathrm{Cd}, \mathrm{Zn})$ is $5700.9897 \mathrm{mg} / \mathrm{kg}$, $2041.1963 \mathrm{mg} / \mathrm{kg}, 7164.7249 \mathrm{mg} / \mathrm{kg}, 21.3295 \mathrm{mg} / \mathrm{kg}$ and $2146.8060 \mathrm{mg} / \mathrm{kg}$ respectively. According to the size the order is: $\mathrm{Pb}>\mathrm{Mn}>\mathrm{Zn}>\mathrm{Cu}>\mathrm{Cd}$. With reference to the State Soil Environment Quality Standard (GB15618-1995), the content of $\mathrm{Cu}, \mathrm{Pb}, \mathrm{Cd}$ and $\mathrm{Zn}$ are 40.82 times, 28.66 times, 71.09 times and 10.73 times than that of the $2^{\text {nd }}$ class while $\mathrm{Cu}, \mathrm{Pb}, \mathrm{Cd}$ and $\mathrm{Zn}$ and also goes beyond the soil environment quality level 3 standard and 5.10 times, 14.3 times than that.

c. The choice of evaluation method for the assessment on soil pollution is very important, different method reflects the different results. The results shows the pollution is heavy by using the single contamination pollution index method and Nemero comprehensive pollution index method; And it shows that $\mathrm{Mn}$ and $\mathrm{Zn}$ are mild ecological risks while $\mathrm{Cu}, \mathrm{Pb}$ and $\mathrm{Cd}$ are extreme heavy with Hankanson potential ecological risk index; Geoaccumulation index evaluation results show that Mn pollution is for level 3, $\mathrm{Cu}, \mathrm{Pb}, \mathrm{Cd}$ pollution at level 6, the pollution of $\mathrm{Zn}$ level between $4 \sim 5$. However the four evaluation methods are based on the total amount of heavy metals as an index to evaluate without taking into account geometrical shape of heavy metals in soil. In fact, the heavy metals in soil exist in many forms, different forms of the element may have different toxicity (). Some references show that it is impossible to make precise prediction assessment of heavy metal pollution degree and soil heavy metal biological effectiveness () only on the basis of the total amount of soil heavy metals. So it is necessary to carry out further study in the region later on.

\section{REFERENCES}

[1] Meng G.T, Fang X.J, Chai Y, et.al, Effect of Vegetation Restoration Measures on Soil Nutientsand Species Diversity in Abandoned Area of Jingning Phosphorite Mine[J]. Journal of Northwest Forestry University,2011,26(3):12-16.

[2] Zhu Y.H, Zhao C.Y, Zhang P.J, et.al, Soil Animals in Abandoned Mine Land and Its Research Advances[J].Chinese Journal of Ecology,2011,,30(9):2088-2092.

[3] Cui X.Y, Guo W.J, Chen X.J, Bioaccumulation Characteristics of Dominant Plants in Siding $\mathrm{Pb}-\mathrm{Zn}$ Mine [J] Metal Mine.,2010,(4):180-182.

[4] Wang Q.R, Liu X.M, Cui Y.S, et.al, Soil Contamination and Sources of Heavy Metals at Individual Sites of Industry and Mining Associate with Wastewater Irrigation in China[J].ACTA ScienTiAE CIRCUMSTANTIAE,2002,22(3):354-358. 
[5] Gan F.W, Fang W.X, Wang X.L, et.al, The Heavy Metal Contamination in Soil-Potato and Pea of Tin Tailings[J].Ecology and Environment,2008,17(5):1847-1852.

[6] Zhang Z.H, Fang X.J, Meng G.T, et.al, Preliminary Study on the Control System of NonPointSource Pollution in Abandoned Land of Mining Area[J] Journal of Anhui Agri Sci.,2010,38(6):8622-8623,8649.

[7] Müller G.. Index of geoaccumulation in sediments of the Rhine River[J]. Geojoural, 1979, 2:108.

[8] Hakanson L. An ecological risk index for aquatic pollution control : A sediment logical approach[J]. Water Research, 1980, 14(1):975-1001.

[9] National Soil Census Office, China Soil[M]. Beijing:Chinese Agricultural Press, 1998.

[10] Shen S.M, China Soil Fertility[M].Beijing:Chinese Agricultural Press, 1998.

[11] Lei D.M, Duan C.Q, Wang M, Soil Fertility and Heavy Metal Contamination in AbandonedRegions of Different Mine Tailings in Yunnan Province[J].Journal of Agro-Environment Science,2007,26(2):612-616. 